\title{
Seedling growth and survival of five tree species in secondary forests and adjacent pastures in the montane rain forests of Southern Costa Rica
}

\author{
Juan Manuel Ley-López ${ }^{1}$, Gerardo Avalos ${ }^{1,2}$ \& Eduardo Chacón-Madrigal ${ }^{1,3}$ \\ 1. Escuela de Biología, Universidad de Costa Rica; 11501-2060 San José, Costa Rica; juanmacrbiol@gmail.com \\ 2. The School for Field Studies, Center for Sustainable Development Studies, 100 Cummings Center, Suite 534-G \\ Beverly, MA 01915-6239 USA; avalos@fieldstudies.org \\ 3. Faculty Centre of Biodiversity, University of Vienna, Rennweg 14, 1030 Vienna, Austria; edchacon@gmail.com
}

Received 13-IV-2015. Corrected 17-VI-2016. Accepted 20-VII-2016.

\begin{abstract}
Successful forest restoration in tropical environments is limited by the paucity of studies on the initial establishment and early survival requirements of seedlings of most native tropical tree species under disturbed conditions. Here, we evaluated the initial growth responses and the regeneration potential of seedlings of five tree species native to Costa Rica (Hasseltia floribunda, Inga densiflora, Persea americana, Tapirira mexicana and Trichilia pittieri). Seedlings were grown in secondary forests and adjacent open pastures under contrasting conditions of light availability. We quantified seedling growth, survival and herbivory from August 2010 to August 2011 on a monthly basis, and measured differences in leaf mass per area (LMA) at the end of the experiment. We found significant variation in growth responses between the understory of secondary forests and pastures. Growth in height was highest in pastures across all species, with I. densiflora, P. americana and T. mexicana showing the most striking differences. In contrast, $H$. floribunda and $T$. pittieri did not show differences in diameter growth between environments. Except for T. mexicana, herbivory increased throughout the experiment in all the species. Herbivory increased faster in pastures for H. floribunda and T. pittieri and showed higher rates in the forest understory for I. densiflora and P. americana. Seedling survival showed significant differences for all species across environments. Survival of $H$. floribunda and I. densiflora was higher in secondary forests, whereas the other species showed higher survival in pastures. LMA showed higher values in the pastures across all species, showing that individuals exposed to high light conditions had great photosynthetic rate and great leaf construction capacity. Due to their rapid growth and high survival, I. densiflora and T. mexicana showed great potential to restore abandoned pastures and secondary forests. Increasing our knowledge on the response of seedlings under disturbed conditions in tropical ecosystems is critical for improving the restoration of altered environments by matching the ecological amplitude of native species with specific environmental conditions. Rev. Biol. Trop. 64 (4): 1565-1583. Epub 2016 December 01.
\end{abstract}

Key words: ecological restoration, leaf mass per area, pastures, reforestation, secondary forest, seedling growth, shade tolerance, tree ecology.

Many tropical areas are dominated by regenerating secondary forests and abandoned pastures, as they recover from intense deforestation, agriculture, and cattle ranching (FAO, 2010). These habitats comprise $45 \%$ of the remaining 11 million $\mathrm{km}^{2}$ of tropical forests (ITTO, 2002), and thus, it is critical to understand their successional dynamics and their role maintaining a portion of the diversity characteristic of primary forests (Chazdon et al., 2009). If managed properly, secondary forests and pastures can increase their conservation value, their capacity to sequester carbon, and their overall contribution to environmental services (Wright \& Muller-Landau, 2006). However, the basic ecological processes limiting plant dispersal, survival, and performance into these habitats are still poorly understood 
as the information on the regeneration requirements of most native species under altered habitat conditions is lacking (Holl, Zahawi, Cole, Ostertag, \& Cordell, 2011; Guariguata \& Ostertag, 2001; Gardner, Barlow, Sodhi, \& Peres, 2010).

The regeneration of disturbed habitats is influenced by the dispersal ability and environmental tolerance of colonizing species (i.e., Martínez-Ramos \& Soto-Castro, 1993; Holl, Loik, Lin, \& Samuels, 2000). Species reaching secondary forest fragments must deal with variable levels of shade and limited opportunities for increasing biomass, whereas species dispersing into pastures must face extremes in physical and biological conditions such as excessive light, high temperatures, water stress, competition with aggressive grasses, and high herbivory (Nepstad, Uhl, Pereira, \& da Silva, 1996; Holl, 2002; Chazdon, 2003; 2008). The presence of primary forest remnants, and the general landscape context (i.e., frequency, shape, and area of forest remnants, Chazdon et al., 2007; Chazdon, 2014) determine the regeneration potential of secondary forests and abandoned pastures and their capacity to recover species diversity and biomass to levels comparable to those of primary forests (Dent \& Wright, 2009; Letcher \& Chazdon, 2009). However, due to the lack of detailed information on the regeneration requirements and environmental tolerances of the majority of native species, most restoration projects use a reduced number of introduced widespread species in addition to a handful of native species (D’Antonio \& Meyerson, 2002; Weber, Günter, Aguirre, Stimm, \& Mosandl, 2008). Consequently, restored habitats have a simpler structure, low species diversity, and low food web complexity (Ewel et al., 1999). Understanding how young seedlings of native trees survive shade conditions in secondary forests and excessive radiation in pastures is fundamental to generate sound management alternatives to restore the diversity and ecological functioning of degraded forests and abandoned pastures.

The ability to grow in different environments can be quantified by examining changes in seedling relative growth rate (RGR) and leaf structure (Villar et al., 2004). For instance, leaf mass per area (LMA) is one of the most important structural characters predicting differences in RGR as well as shade / sun adaptation (Kitajima, 1994; Reich, Walters, \& Ellsworth, 1997; Poorter, Niinemets, Poorter, Wright, \& Villar, 2009). High LMA is a characteristic of sun-adapted species with high RGR, resulting in higher light interception with less investment in leaf biomass. LMA scales with photosynthetic capacity functioning as a proxy to predict plant functional performance (Reich et al., 1997; Osnas, Lichstein, Reich, \& Pacala, 2013; Reich, 2014). Pioneer species generally have high photosynthetic rates, high biomass production, and high values of RGR and LMA (Reich, Tjoelker, Walters, Vanderklein, \& Buschena, 1998; Poorter \& De Jong, 1999). In contrast, shade-tolerant species have slow growth and low LMA (Valladares \& Niinemets, 2008; Markesteijn \& Poorter, 2009). Many shade-tolerant tree species express slow growth and low survival in pastures as compared to their response under shade due to the adverse microclimatic conditions dominating open pastures (Nepstad et al., 1996; Holl et al., 2000). Nonetheless, some species can establish successfully in pastures once they overcome dispersal barriers (Butterfield, 1995; Leopold, Andrus, Finkeldey, \& Knowles, 2001; GarcíaOrth \& Martínez-Ramos, 2008).

Our main objective here was to analyze the growth and survival of seedlings of the shade tolerant, native tree species Hasseltia floribunda Kunth. (Flacourtiaceae), Inga densiflora Benth. (Fabaceae / Mimosoidae), Tapirira mexicana Marchand. (Anacardiaceae), Trichilia pittieri C. DC. (Meliaceae), and Persea americana Mill. (Lauraceae), growing in secondary forest fragments and adjacent pastures, in a montane rainforest in Southern Costa Rica. We compared seedlings in terms of differences in LMA, as well as intra-and interspecific variation in height and diameter growth, herbivory damage and survival after a year of exposure to the contrasting environment of the forest understory of secondary forest fragments 
and adjacent pastures. We expected to segregate the species into their regeneration strategies following their performance in opposite environmental conditions of abandoned pastures and secondary forests. Analyzing the growth, survival and physiological requirements of young seedling established under harsh conditions, broadens the baseline of the ecophysiological knowledge of native species and improves management and restoration strategies, focused on the regeneration capacity of secondary forests and abandoned pastures (Álvarez-Aquino, Williams-Linera, \& Newton, 2004).

\section{MATERIALS AND METHODS}

Study site: This research was carried out from December 2009 to August 2011 at Las Cruces Biological Station (LCBS 8 $47^{\prime} 07^{\prime \prime}$ $\left.\mathrm{N}-82^{\circ} 57^{\prime} 32^{\prime \prime} \mathrm{W}\right)$ and the community of Agua Buena de Coto Brus ( $8^{\circ} 44^{\prime} 42^{\prime \prime} \mathrm{N}-82^{\circ} 56^{\prime} 53^{\prime \prime}$ W) in Southeastern Costa Rica. The site corresponds to a tropical montane moist forest (Holdridge, 1978), with an annual rainfall of $3500 \mathrm{~mm}$ and an average annual temperature of $20{ }^{\circ} \mathrm{C}$. The dry season goes from December to March. The site is located between 1000 and 1300 masl. Soils are dominated by Andisols, which are formed by volcanic deposits and weathering by acid rain. Andisols are rejuvenated and enriched by andesitic volcanic ash additions and have relatively moderate fertility. However, some studies indicate that in this area the soils are dominated by plagioclases over orthoclases, which create a pronounced Potassium deficiency (Henríquez \& Bertsch, 1994; Alvarado \& Mata 2015). The region was largely forested until approximately 1950 , when most of the land was converted into coffee plantations. However, the drop in the international price of coffee led to the replacement of coffee plantations to other land uses (mainly pastures) or their abandonment, which allowed natural regeneration (Rickert, 2005). Currently, the landscape is largely deforested and characterized by a mosaic of pastures, agriculture and small remnants of secondary forests concentrated along steep slope conditions and near rivers (Zahawi, Duran, \& Kormann, 2015). LCBS maintains the largest remaining fragment of primary forest in the immediate region. Less than $27 \%$ of the area surrounding LCBS remains forested (Daily, Ehrlich, \& SánchezAzofeifa, 2001). Due to the high levels of deforestation and land erosion, most of the conservation efforts are focused in the restoration of degraded lands (Holl et al., 2011).

Study species: We chose five native tree species with different regeneration strategies Hasseltia floribunda Kunth. (Flacourtiaceae), Inga densiflora Benth. (Fabaceae / Mimosoidae), Persea americana Mill. (Lauraceae), Tapirira mexicana Marchand. (Anacardiaceae) and Trichilia pittieri C. DC. (Meliaceae). A summary about the characteristics of the studied species is given in Table 1.

Seedling collection: Seedlings from $I$. densiflora where obtained from seeds collected in December 2009. For the rest of the species, recently germinated seedlings were collected following the trails within a primary forest fragment at LCBS, between September and December 2009. Seeds and recently germinated seedlings were planted in plastic bags of $6 \times 8 \mathrm{~cm}$ filled with soil taken from the field. All seedlings were grown in the greenhouse of LCBS. The greenhouse was covered with green shade cloth and seedlings were irrigated daily during the dry season and kept in the nursery until transplantation to the field. The maintenance in the nursery for seven months allowed the homogenization of initial conditions for all the individuals. Transplantation into the field was done in August 2010 during mid rainy season to avoid the risk of drying out and increase the probability of survival. We selected seedlings of similar size and excluded plants damaged by herbivores or disease.

Plot location: We worked in four sites having secondary forest fragments and adjacent pastures. The sites were separated by at least $1 \mathrm{~km}$ and shared a common history of land use. Secondary forest fragments had 15-25 years 


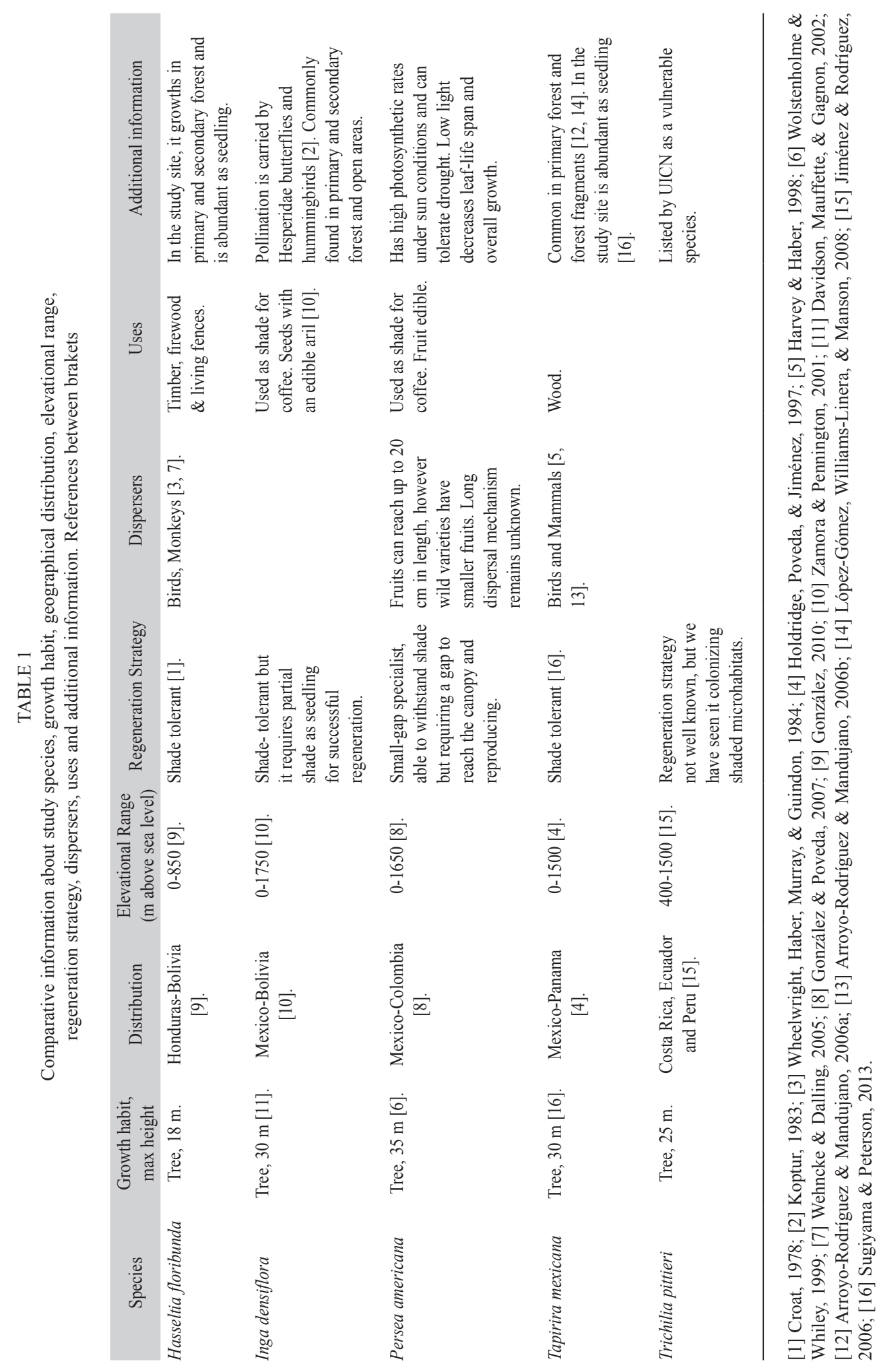


of regeneration and were at least 15 ha in size. As with most of the remaining forests in the area, the fragments were originally used for coffee production and cattle ranching and were located along rivers or steep terrain. Canopy height ranged 10-20 $\mathrm{m}$, and forest cover ranged $75-86 \%$. The pastures were used for agriculture or cattle ranching for at least 15 years, but were recently abandoned. Soils are volcanic, moderately acidic with high inorganic matter and low phosphorus (Holl et al. 2011). We do not have information about specific differences in soil conditions between plot sites; however, previous studies in the area have shown that abandoned pastures have a great variation in nutrient levels and soil compaction (Holl et al. 2011). Pastures were dominated by exotic grasses, such as Axonopus scoparius (Flüggé) Kuhlm., Pennisetum purpureum Schumach. and Urochloa brizantha (Hochst. ex A. Rich.) R.D. Webster. Other common plants present in pastures included ruderal herbs, ferns, shrubs, small trees, and typical pioneer species such as Cecropia obtusifolia Bertol., Conostegia xalapensis (Bonpl.) D. Don ex DC., Croton draco Schltdl. \& Cham., Heterocondylus vitalbae (DC.) R.M. King \& H. Rob., and Pteridium arachnoideum (Kaulf.) Maxon.

In August 2010, we established 24 plots of $12 \times 12 \mathrm{~m}$. Three plots were established in each site (see above) within the secondary forest fragment while three plots were placed in random locations in adjacent pastures, maintaining at least $10 \mathrm{~m}$ of distance relative to the nearest forest edge. Plots within forest fragments were established in a stratified manner, avoiding large gaps while keeping a distance of at least $30 \mathrm{~m}$ from the edge. At three sites the pastures were abandoned and left for natural regeneration, but at the fourth site, cattle-ranching was still in place, and thus the study plots were fenced to exclude cattle. Five seedlings per species were planted within each plot both in secondary forest fragments and in pastures, keeping a distance of $2 \mathrm{~m}$ between seedlings, and distributed randomly. A total of 120 seedlings per species were planted, resulting in
30 seedlings per species per location, and 15 seedlings per species in each habitat type. Due to the lack of sufficient $T$. mexicana seedlings, this species was replicated in only three out of the four sites for both secondary forest fragments and pastures.

Seedling growth and survival: We carried out monthly measurements of height, diameter, number of leaves, herbivory damage, and seedling survival from August 2010 to August 2011. Seedling height was measured from the base of the stem to the tip of the highest meristem. Stem diameter was measured at the base of the stem right above the ground. Herbivory damage was recorded visually by estimating the percentage of leaf area loss for each leaf using a scale of 0 to 5 as follows: $0=$ absence of damage, $1=1-20 \%, 2=21-40 \%$, $3=41-60 \%, 4=61-80 \%, 5=81-100 \%$, where $100 \%$ is whole leaf being lost. The percentage herbivory damage was average per plant. For the survival analysis, we considered dead seedlings as plants without leaves and with a dry stem at the time of measurement. Dead seedlings were checked during successive visits to corroborate the lack of recovery.

Measurement of LMA: At the end of the experiment (August 2011), we collected one leaf from all surviving seedlings to determine LMA following the methodology of Garnier, Shipley, Roumet and Laurent (2001). In every individual, we selected the youngest full expanded leaf with at least $80 \%$ of the leaf blade intact. Although we tried to collect leaves without herbivory or pathogen damages this was not possible for some seedlings growing in pastures. Leaf area was measured with a leaf area meter (Delta-T area meter-Devices) and all leaf samples were oven-dried at $60{ }^{\circ} \mathrm{C}$ until constant weight.

Measurement of canopy structure: We took hemispherical photographs in January 2011 to measure canopy openness and leaf area index (LAI) and assess how canopy structure 
affected seedling growth in the understory of secondary forests. Photographs were taken in the corners and at the center of each plot at a fixed height of $1.5 \mathrm{~m}$ above the ground, aligning the top of the camera lens with the magnetic North. Photographs were taken before 9 am, or after $3 \mathrm{pm}$, under overcast conditions to prevent direct flecks of light to blur the contrast between canopy cover and open sky (Rich, 1990). Photographs were not taken in pastures due to the absence of a forest canopy there. Photographs were analyzed using Gap Light Analyzer (Forest Ecology Lab, Canada).

Statistical analysis: We used mixed-effect models (containing random and fixed effects) to analyze seedling growth (growth in height and diameter, and the number of leaves), as well as herbivory damage. We tested the effects of time (represented by the fixed-effect coefficient for time - 1), environment (which tested differences between secondary forests and pastures at the beginning of the experiment) and the interaction between time (time-1) and environment (secondary forest vs. pasture). We considered the effect of individual seedlings as random. Besides, we analyzed the data using site as a random effect and we compared models with Akaike information criterion, however the site had not effect, therefore we maintained and presented only the models without site as random effect. The models for variables height and diameter were corrected for the autocorrelation of errors within individual seedlings. We used the following fully crossed generalized linear model:

$$
Y_{n m e}=\theta+\alpha_{\mathrm{m}}+\beta_{\mathrm{e}}+(\alpha \beta)_{\mathrm{me}}+\gamma_{\mathrm{n}}+\varepsilon_{\mathrm{nme}},
$$

where $n$ denotes the individual seedling, $m$ corresponds to the month, $e$ to the environment (secondary forests or pastures), Ynme is the measure of height, diameter, number of leaves or herbivory, $\theta$ is the overall mean of the corresponding variable (height, diameter, number of leaves, herbivory), $\alpha_{\mathrm{m}}$ and $\beta_{\mathrm{e}}$ correspond to the "time" and "environment" fixed effects, respectively, $\gamma_{\mathrm{n}}$ is the "individual" random effect, $(\alpha \beta)_{\text {me }}$ is the interaction term, and $\varepsilon_{\text {nme }}$ is the random error. For this analysis, we used the R packages nlme (Pinheiro, Bates, DebRoy, Sakar, \& R Core Team, 2014) and lattice (Sarkar, 2008). To determine the effect of habitat type on seedling survival, we implemented a survival analysis using the product limit method (Kaplan-Meier) for census groups. For each species, we tested differences in survival curves between individuals growing in secondary forests and in pastures. To test differences among environments we used the Mantel-Haenszel test and the R package Survival (Therneau, 2014).

We tested with a two-way factorial ANOVA the effect of species and environment (understory of secondary forests and pastures) in LMA. The LMA values were log-transformed to adjust the deviations of normality and equality of variances (Quinn \& Keough, 2002). A posteriori differences between groups (species and environment) were measured using a posteriori Tukey HSD tests. We measured differences in canopy structure between sites using a Kruskall Wallis test. All analyses were performed using R software (http://www.r-project.org).

\section{RESULTS}

Variation in seedling stem height and diameter: Growth in height increased faster in pastures relative to secondary forests, especially in I. densiflora and P. americana, followed by $T$. mexicana. In contrast, $H$. floribunda and T. pittieri had small height differences between secondary forests and pastures (Table 2, Fig. 1). Within secondary forests, growth in height was low across species, with 4 out of 5 species showing annual average increments of less than $3.5 \mathrm{~cm}$ (except for T. mexicana, which had an average annual increase of $6 \mathrm{~cm}$ ). All species significantly increased height in pastures, with average values increasing $30-300 \%$ relative to the initial size (Fig. 1). Changes in diameter followed the same pattern across species and environments. Inga densiflora, T. mexicana and $P$. americana had a much greater increase in diameter in pastures (Table 2, Fig. 1). 


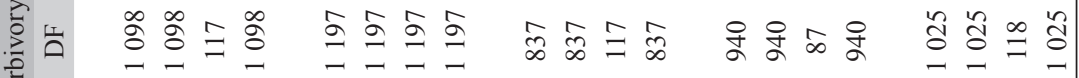

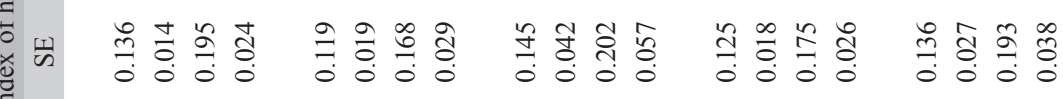

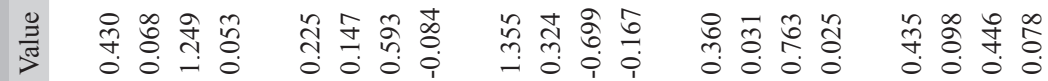

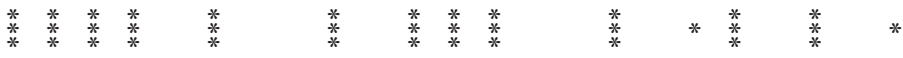

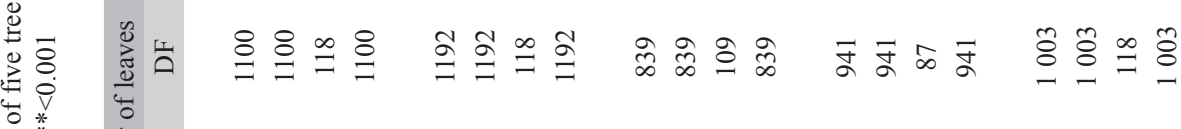

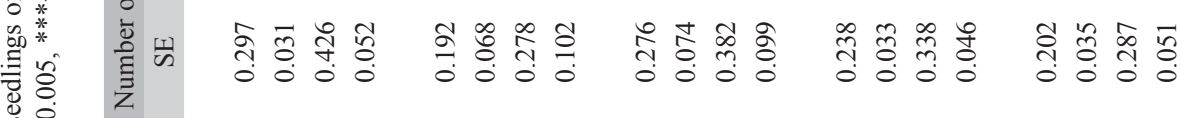

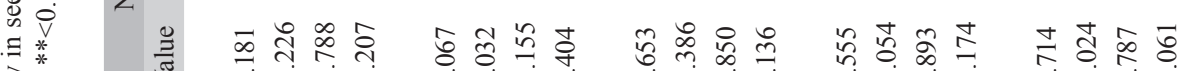

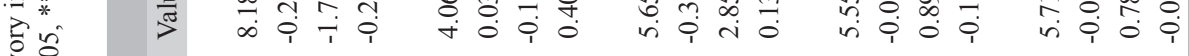

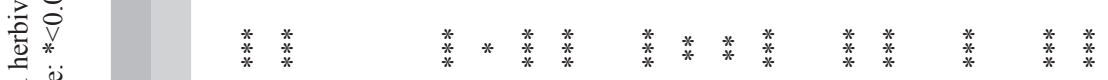

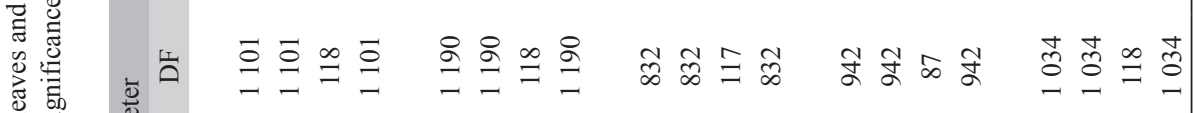

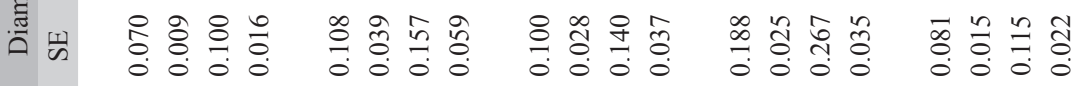
氙

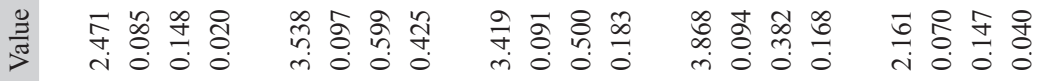
$\Rightarrow$

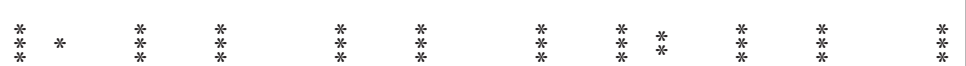

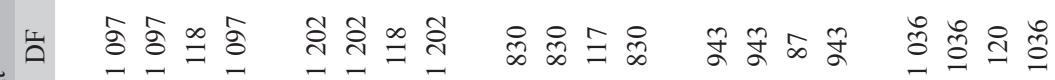

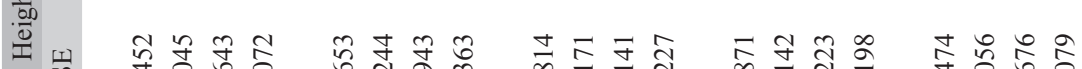

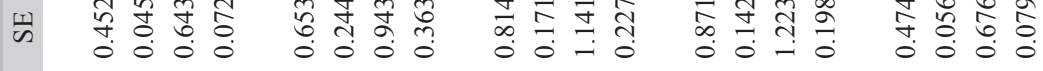

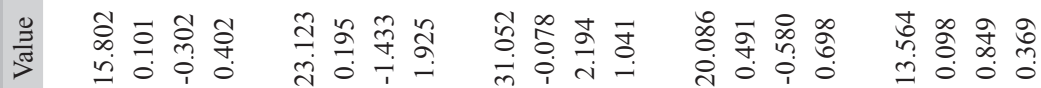

离

$\stackrel{9}{\Xi}$

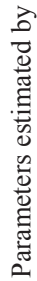

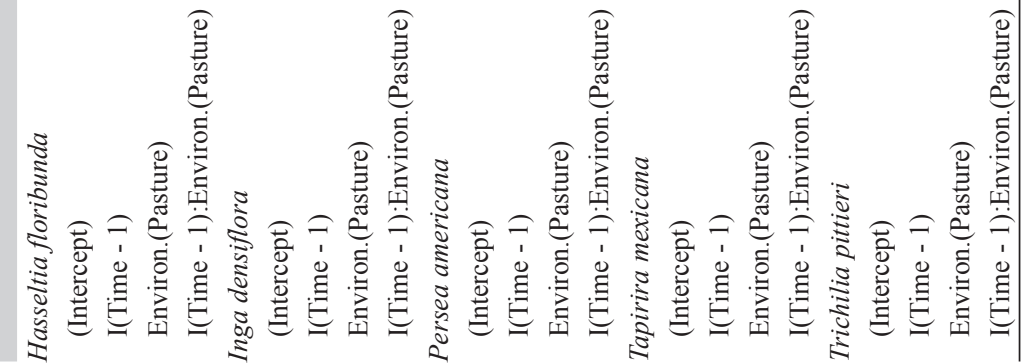



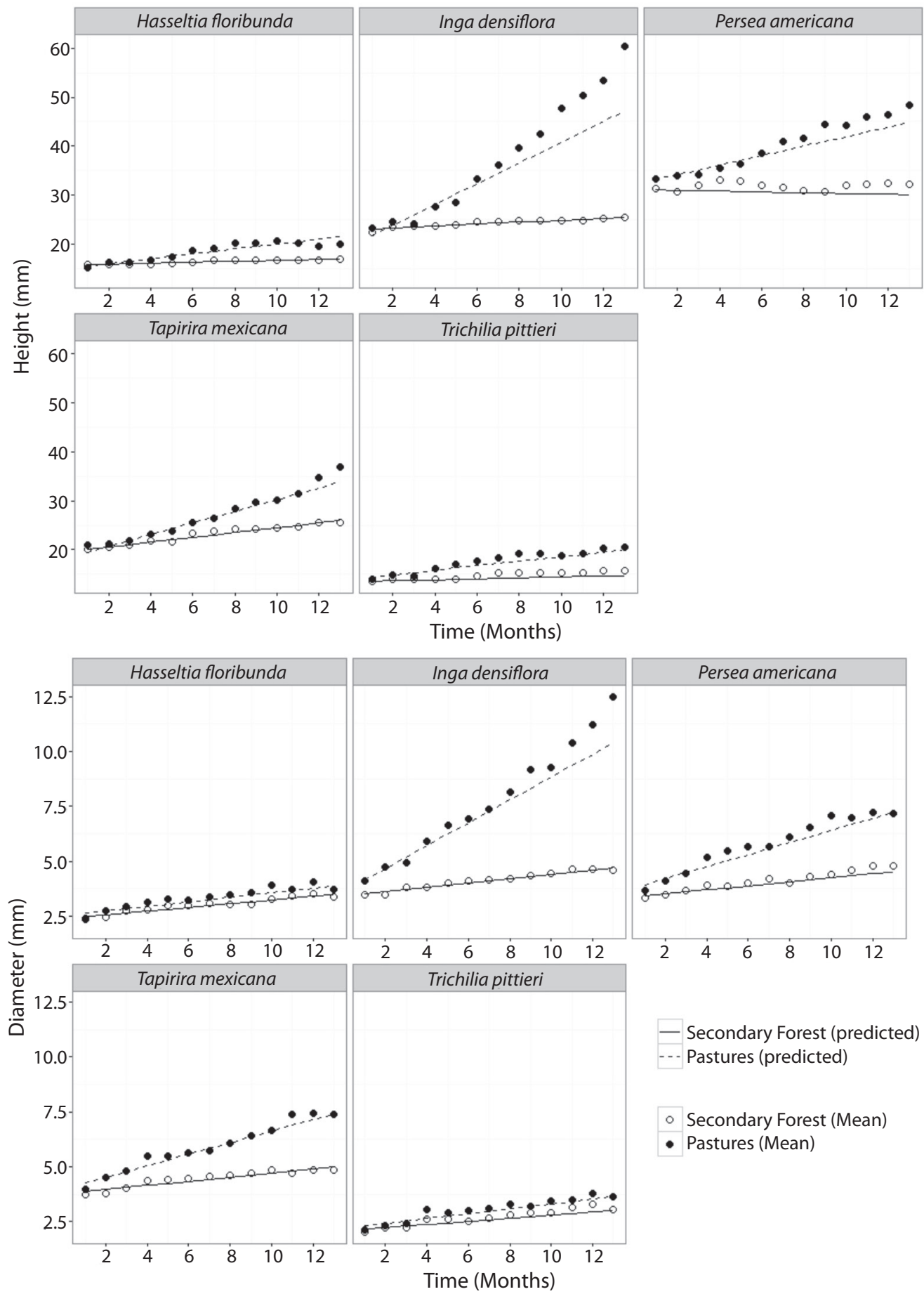

Fig. 1. Monthly means of height and diameter in seedlings of five tree species growing in forest or pastures during 13 months. Lines represent predicted values according to mixed models. 
Variation in leaf numbers: Seedlings of T. pittieri, I. densiflora and P. americana had significantly more leaves in pastures than in secondary forests; by contrast, seedlings of H. floribunda had more leaves in secondary forests (Table 2, Fig. 2). Hasseltia floribunda and $P$. americana decreased leaf numbers in secondary forests and pastures throughout the experiment, whereas $T$. mexicana decreased leaf numbers only in pastures (Table 2, Fig. 2). Inga densiflora was the only species increasing leaf numbers in pastures (Table 2, Fig. 2). Seedlings of $H$. floribunda, and T. mexicana decreased leaf numbers faster in pastures than in the secondary forests where leaf numbers did not change significantly over time in $T$. mexicana (Table 2, Fig. 2).

Variation in levels of herbivory: The index of herbivory was consistently higher in pastures for T. mexicana, T. pittieri, and $\mathrm{H}$. floribunda, and in secondary forests for P. americana. Except for T. mexicana and P. americana, herbivory increased throughout the experiment. Herbivory increased faster in pastures for $H$. floribunda and T. pittieri, and was higher in secondary forests for I. densiflora and P. americana towards the end of the experiment (Table 2, Fig. 2). The tendency showed a sustained increased in herbivory, which peaked around the fourth and sixth month, and then decreased in all species.

Seedling survival: Survival trajectories of $H$. floribunda and I. densiflora were higher in secondary forests, whereas the rest of the species presented higher survival in pastures (Table 3, Fig. 3). Hasseltia floribunda and I. densiflora had high mortality in pastures (more than $50 \%$ of individuals were lost in pastures), but in the secondary forests they lost only 6 and 5 seedlings, respectively, throughout the study period. Tapirira mexicana had an overall low mortality, whereas $T$. pittieri lost more than 50 $\%$ of the initial seedlings in both environments (Fig. 3, Table 3). Persea americana showed the highest mortality of all species in both environments, although survival was higher in pastures. The high survival of $H$. floribunda and $I$. densiflora in the secondary forests was associated with slow growth in the shade (Fig. 3, Table 3).

Variation in LMA: We found differences among species and environments in LMA $\left(\mathrm{r}^{2}\right.$ $\left.=0.63, \mathrm{~F}_{9,277}=53.8, \mathrm{P}<0.001\right)$. LMA was consistently higher in pastures relative to secondary forest $\left(\mathrm{F}_{1,277}=237.9, \mathrm{P}<0.001\right.$, Fig. 4), however the difference in LMA between environments within species was significant among species $\left(\mathrm{F}_{4,277}=7.34, \mathrm{P}<0.001\right)$; the difference in LMA between environments was large for some species as Inga densiflora but small for species as $H$. floribunda (Fig. 4). The LMA also varied between species $\left(\mathrm{F}_{4,277}=54.22\right.$, $\mathrm{P}<0.001$ ), Tapirira mexicana had the highest LMA but not significantly different to $T$. pittieri and $P$. americana (Tukey HSD P $>0.05$ ), Inga densiflora and H. floribunda had lower LMA

TABLE 3

Results of the Mantel-Henszel test comparing survival curves after 13 months in seedlings of five tree species growing in the understory of secondary forests ( SF) and in adjacent pastures (P), where $\mathrm{N}$ is the overall number of records ( $\mathrm{dead}=0$ or alive $=1$ ) and the observed (Obs.) is the number recorded as alive. The symbol * denotes statistically significant differences

\begin{tabular}{lccccccc}
\multicolumn{1}{c}{ Species } & N (SF) & N (P) & Obs. (SF) & Obs. (P) & $\chi 2$ & df & $p$ \\
Hasseltia floribunda & 781 & 715 & 36 & 241 & 193 & 1 & $<0.001^{*}$ \\
Inga densiflora & 789 & 715 & 35 & 151 & 90.2 & 1 & $<0.001^{*}$ \\
Persea americana & 780 & 715 & 340 & 207 & 26.8 & 1 & $<0.001^{*}$ \\
Tapirira mexicana & 585 & 585 & 78 & 55 & 4.2 & 1 & $0.04^{*}$ \\
Trichilia pittieri & 780 & 715 & 192 & 142 & 4.4 & 1 & $0.037^{*}$ \\
\hline
\end{tabular}



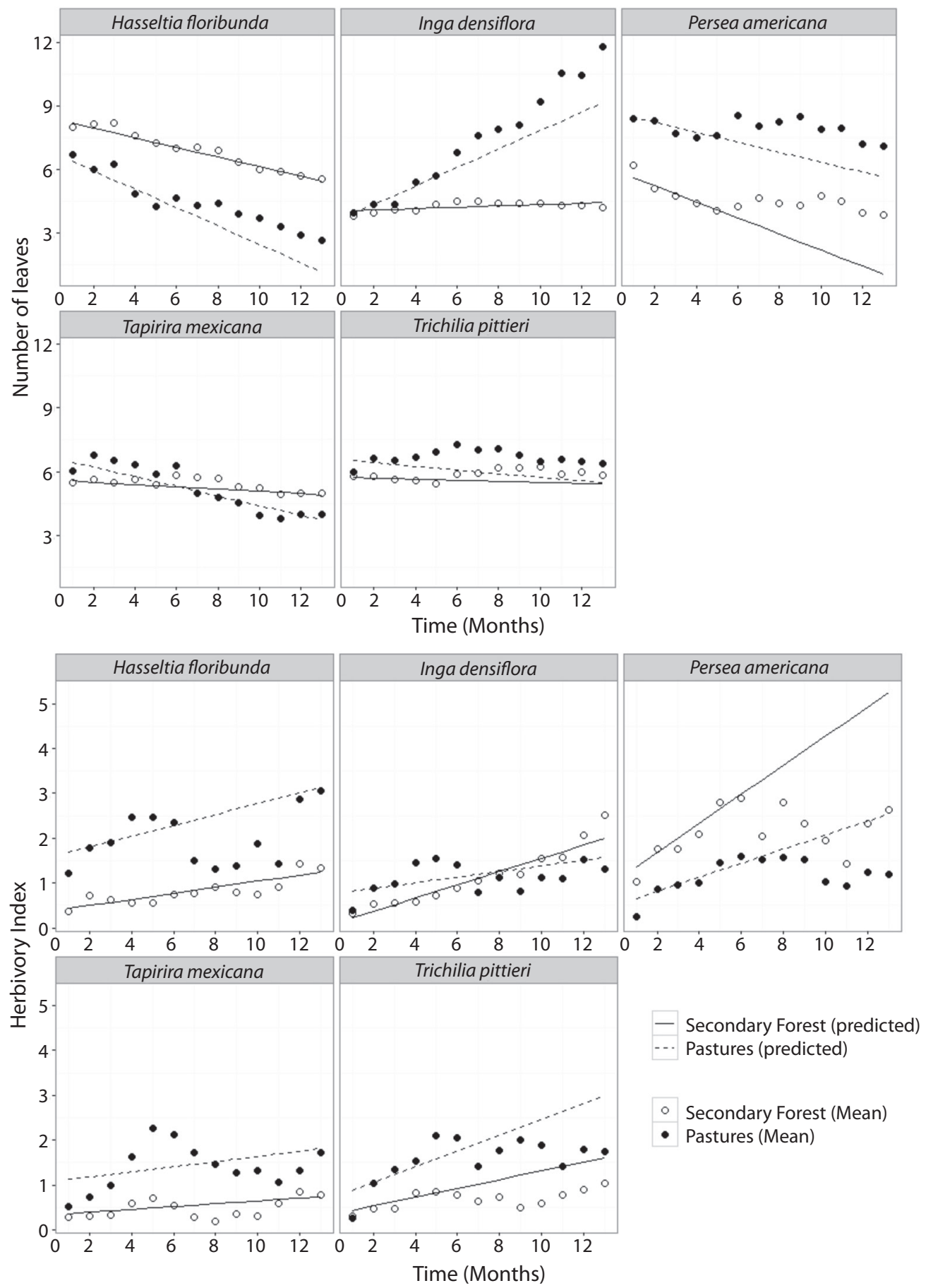

Fig. 2. Monthly means of number of leaves and the index of herbivory for seedlings of five tree species growing in the understory of secondary forest and in pastures during 13 months. Lines represent predicted values according to mixed models. 

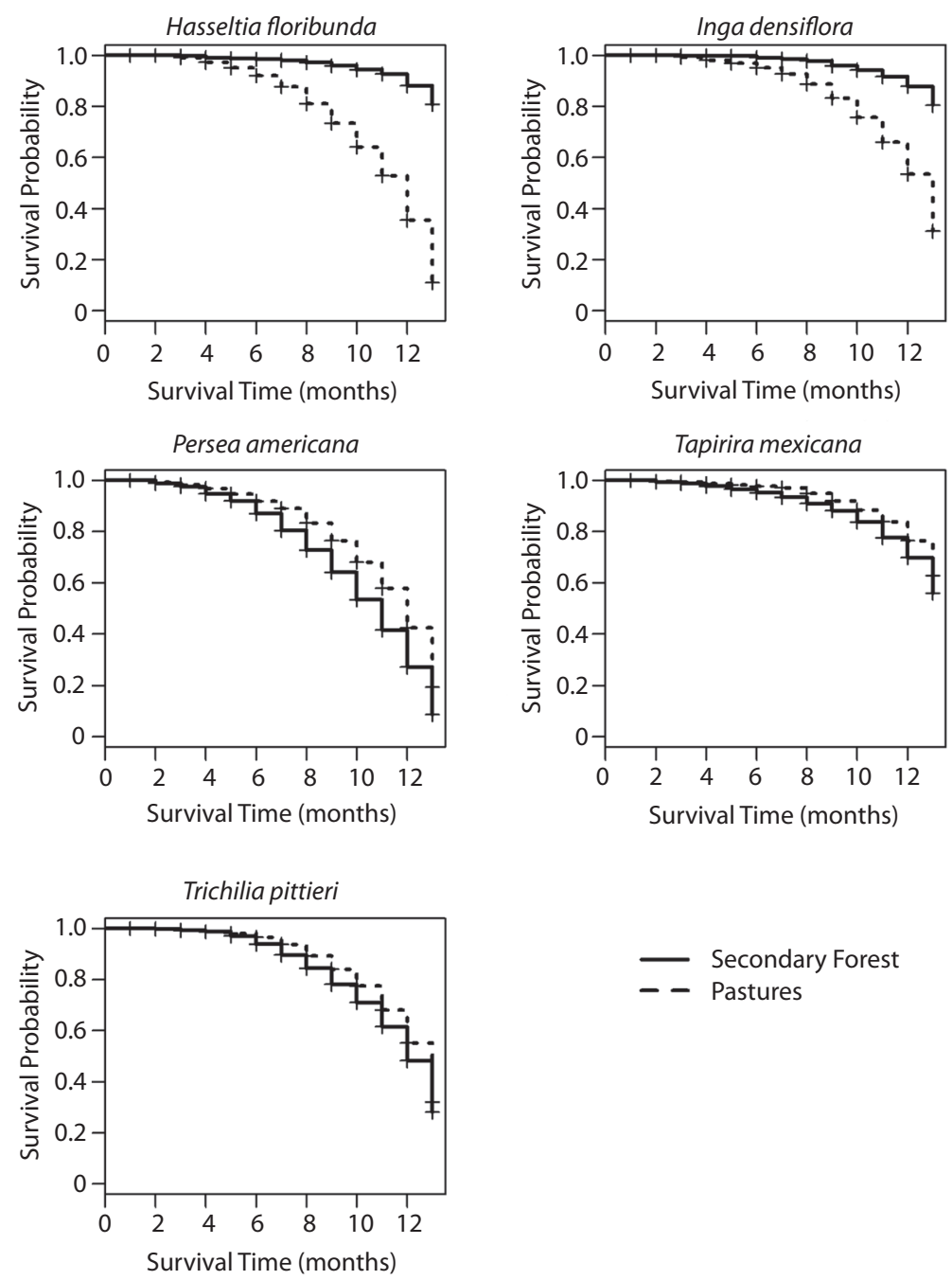

Fig. 3. Survival probability curves of seedlings of five tree species growing in the understory of secondary forests and in adjacent pastures.

values and significant differences between them (Tukey HSD $\mathrm{P}<0.05$ ) (Fig. 4).

Variation in forest structure and light conditions within secondary forests: Average canopy openness in the four secondary forest sites was $18.6 \%$ with values ranging from 13.9 to $24.1 \%$. Canopy openness did not change significantly between sites (KruskalWallis $=7.264, \mathrm{df}=3, \mathrm{P}=0.06$ ). LAI values varied between 1.5 and 2.04, with an average of
1.77. Differences in canopy openness and LAI between sites did not affect seedling growth and survival within forest fragments.

\section{DISCUSSION}

In this study, we found a variety of growth responses to different light conditions in two environments. Hasseltia floribunda and I. densiflora survived well in the secondary forest, whereas $T$. mexicana maintained a high 


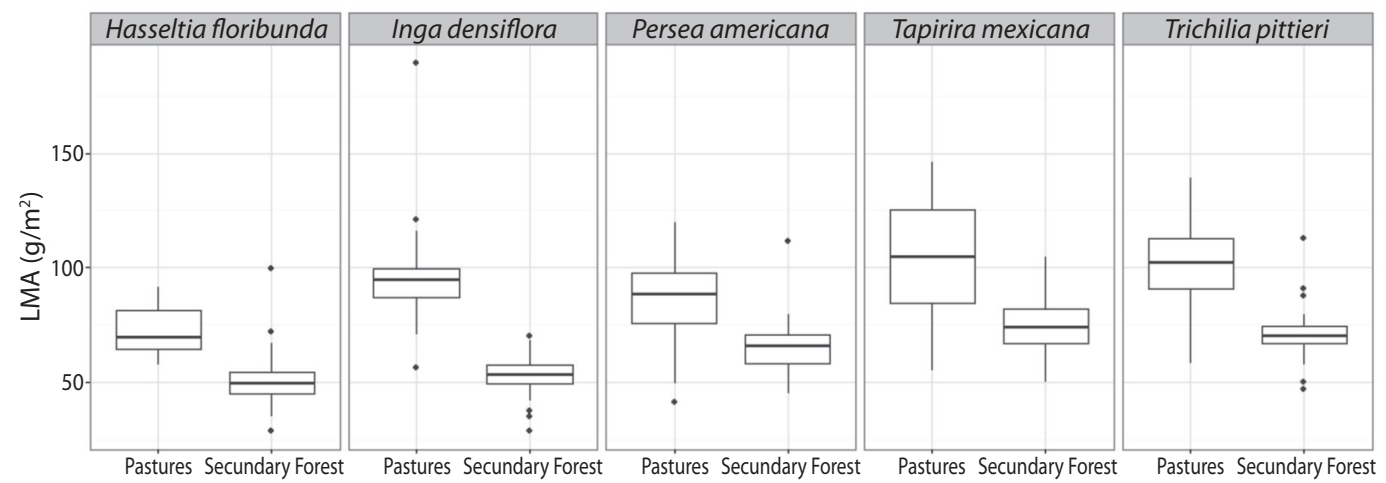

Fig. 4. Leaf mass per area (LMA) of seedlings of 5 tree species in the understory of secondary forests and in pastures. Plants growing in pastures had higher LMA than plants growing in secondary forest across all species. Horizontal lines represent the median, boxes represent the $25^{\text {th }}$ and $75^{\text {th }}$ percentiles, whiskers represent $95 \%$ confidence intervals according to the normal distribution, and points represent outliers.

survival rate in both secondary forests and pastures. Persea americana showed the highest mortality, but at the same time, it had high growth in pastures. Finally, T. pittieri showed low survival and growth in both environments.

Due to its good survival and growth Tapirira mexicana has a great potential to restore pastures and secondary forests. The species had high growth under shade and intermediate growth in pastures, showing a flexible response to light availability. This species showed the highest values of LMA in both environments, which is an indicator of high photosynthetic rate (Kitajima, 1994). Despite being a species typical of mature forests, T. mexicana is common in forest fragments and areas close to forest edges (Arroyo-Rodríguez \& Mandujano, 2006a; Sugiyama \& Peterson, 2013). Sugiyama \& Peterson (2013) found high mortality in T. mexicana during the first year after germinating close to the forest edge, however after this period, seedlings were able to adapt to increased light levels. This could explain the variability observed in this species, with some individuals dying and some growing satisfactorily, since at the time of planting these seedlings had eight months in the nursery and were more mature.

Inga densiflora showed the highest growth in pastures and, being a nitrogen-fixing species, has great potential to restore degraded areas. Davidson, Gagnon, Mauffette and Hernández (1998) reported for I. densiflora survival levels higher than $90 \%$ in degraded pastures, higher than the levels observed here. The reason for this difference could be that the initial average height reported by Davidson, Gagnon, Mauffette and Hernández (1998) was more than twice the initial average height in our study; this clearly favored growth and survival (Gerhardt, 1994; Martínez-Garza, Tobon, Campo, $\&$ Howe, 2013). The initial diameter and seedling size has shown to influence survival and growth of tree seedlings planted in pastures (Mexal, Rangel, Negreros-Castillo, \& Lezama, 2002). Inga densiflora showed considerable plasticity, expressing the highest difference of LMA values between environments, with high values in the pastures and low values in the secondary forest, which also explains that this species showed the highest growth difference between environments. Inga densiflora is common in both primary forests and open areas and has a wide altitudinal gradient (Zamora \& Pennington, 2001). Thus, it may possess sufficient physiological plasticity to survive a wide range of environmental conditions. Although I. densiflora showed a high survival in the forest, it is possible that it requires the formation of big gaps to establish successfully. 
While differences in growth and number of leaves were almost negligible among individuals in the secondary forest, herbivory increased all year, reaching the highest values at the end of the experiment.

Hasseltia floribunda and T. pittieri showed very slow growth in the understory of secondary forests and in pastures. These species are not suitable for restoration purposes in the studied environments, at least in the very early stages of succession. Hasseltia floribunda could survive under shade conditions, but the ability of this species to grow under low light is limited, this species had the lowest values of LMA and therefore, could have low capacity to increase biomass. In addition, $H$. floribunda is associated with wetlands and riparian forests, then, it could be affected by long drought periods (Harms, Condit, Hubbell, \& Foster, 2001). Finally, some individuals of $P$. americana grew at high rates in the pastures, but were associated with high mortality. Persea americana benefits from moderate light and requires a long time to store resources for growth and reproduction. It has high photosynthetic rates under high light, but is not a typical pioneer species (Wolstenholme \& Whiley, 1999). Since $P$. americana requires a variable period for resource storage, it is not a good choice for pasture restoration, being characteristic of later successional stages. Other strategies should be implemented in order to use these species successfully in restoration projects. In these species, increased growth responses could be improved if the seedlings are kept in nursery conditions until they are large enough to withstand stressful conditions.

Seedling performance varied within and among species for most of the variables measured. In general, growth and LMA were higher in the pastures, while survival, herbivory, and leaf number varied in direction and intensity that depend on the species and the environment. While the adverse abiotic conditions of pastures caused high seedling mortality, the increased light availability could benefit the species and individuals that could cope with the harsh conditions of pastures.
In general, our results are congruent with other studies that have assessed the behavior of native species planted in degraded pastures and secondary forests (Álvarez-Aquino et al., 2004; Muñiz-Castro, Williams-Linera, \& Benítez-Malvido, 2015).

Pastures have compacted and eroded soils, limited fertility and lower water soil content (Nepstad et al., 1996; Holl et al., 2000). This was particularly evident in one site exposed to cattle ranching for nearly 50 years, where only 14 out of 75 seedlings survived. Low nutrient availability is associated with low seedling survival (Cole, Holl, \& Zahawi, 2010). Slowgrowing species are particularly vulnerable to dry periods, since their roots usually do not reach sites with sufficient soil moisture. The increase in seedling mortality caused by exposure to the dry season and prolonged drought is well documented, both in natural conditions and in restoration projects (Gerhardt, 1994; Martinez-Garza et al., 2013).

Growth in height and diameter were in general higher in pastures, and helped compensate for the higher herbivory observed in this environment. The high seedling mortality and high herbivory observed in pastures represents the outcome of the growth/mortality trade-off, which is characterized by growing fast under high light (Denslow, 1987; Guariguata, 2000). These results are congruent with the stress tolerance model (Kitajima, 1994), which proposes that seedling survival is related to a strategy of resource allocation that is mostly opportunistic, increasing growth to compensate for high mortality, or decreasing growth in return for lower mortality. Although diameter and height increased consistently in pastures this was not the case for leaf numbers (except in the case of $I$. densiflora, which maintained and even increased leaf number throughout the study). Low leaf production and increased leaf mortality in pastures could be the result of increased allocation to root biomass due to water stress and low nutrient availability (Gardiner \& Hodges, 1998; Palow \& Oberbauer, 2009).

Forest structure could have affected the magnitude of LMA. All the species consistently 
had higher LMA in pastures relative to secondary forest. This result is congruent with previous results reporting higher LMA under high light (Lusk, Reich, Montgomery, Ackerly, \& Cavender-Bares, 2008). Shade plants were expected to have low photosynthetic rates, and thus lower construction and higher maintenance costs relative to leaves produced under high light, and thus, lower LMA (Valladares \& Niinemets, 2008). Also, the results are consistent with survival patterns; species with high LMA had higher survival in pastures while species with lower LMA had higher survival in secondary forest.

Many tropical areas are regenerating after long periods of deforestation, intense agriculture and cattle ranching. Natural regeneration combined with active reforestation is slowing down the global deforestation rate, although the net rate of forest loss continues to increase as old-growth forests are altered and then replaced by regenerating secondary forests (Wright, 2010; Aide et al., 2013). Most of the regenerating forests and abandoned pastures are heavily degraded and are located within a fragmented landscape, which makes restoration difficult. The species composition of restored forests is affected by the landscape context (Dent \& Wright, 2009), the limited knowledge of the requirements to propagate individual species (Hoffmann, Blum, Velazco, Gill, \& Borgo, 2015), as well as by the specific goals of private owners and local farmers, who favor the regeneration of certain species, using selected species for logging, shade for cattle, fruiting trees, and medicinal purposes (i.e., Häger, Otárola, Stuhlmacher, Castillo, \& Arias, 2015). The sun-shade dichotomy has practical importance but ignores the ample variation found in the regeneration strategies of tropical species; the species analyzed here are no exception. Many species express ontogenetic niche shifts as they increase in height and move from a light-limited environment to more light, or as they acquire resources to survive in the shade or increase growth under sun (Kitajima \& Poorter, 2008; Benitez-Malvido \& MartínezRamos, 2013).
Although it is clear that successional forests and pastures will not reach the same level of species diversity and community structure relative to the original primary forests in the short run (Dent \& Wright, 2009; Gibson et al., 2011), they serve as reservoirs of biodiversity, and if managed properly, they could complement the environmental services provided by primary forests (Gardner et al., 2010; Melo, Arroyo-Rodríguez, Fahrig, Martínez-Ramos, \& Tabarelli, 2013). Conservation efforts should not abandon the protection of mature tropical forests, but at the same time, research should also focus on the ecological determinants of the long-term persistence of biodiversity in humanaltered landscapes by integrating knowledge generated in temperate and tropical areas, hopefully leading to improved management and regenerating of secondary forests and pastures (Lindenmayer, 2010). Increasing our knowledge on the regeneration requirements of tropical species is thus crucial to match seedling requirements with environmental conditions.

Reforestation and restoration projects have increased in the last decades. Nonetheless, our knowledge about the growth and survival of most tropical tree species in degraded habitats is scarce and has mostly limited to a small group of species, usually those with economic importance. Exploring the behavior of different species is relevant in order to achieve successful restoration projects (Palma \& Laurance, 2015). For instance, tropical montane forest is one of the most threatened ecosystem but very few works have addressed the potential of native species to restore this habitat.

In this study, we showed that Inga densiflora and T. mexicana have potential for restoring degraded pastures or forests. In contrast, $H$. floribunda, $P$. americana and T. pittieri showed negative results and other methods should be implemented to improve the establishment success of those species. The differences in growth responses observed within and among species were congruent with the life history strategies of our study species and their level of physiological plasticity to adapt to changing environmental conditions. For instance, 
Inga densiflora and T. mexicana grow naturally inside mature forests but can be found in open areas or forest edges as well.

Since many tropical areas are abandoned after agriculture and cattle ranching, the opportunity to implement successful restoration projects depends on how much we know on the specific physiological requirements of seedlings of native species and their functional growth responses (Wright, 2010). Although the seedling stage is the most critical phase in the life cycle of plants, regeneration studies should include other life stages, such as juveniles and adults, since many tropical species express ontogenetic niche shifts and changes in long-term performance (Dalling et al., 2001; Benítez-Malvido, \& Martínez-Ramos, 2013). Our understanding of the importance of specific functional traits (such as LMA), as well as the variation in suites of functional traits, depends on the implementation of long-term demographic studies with sufficient replicates per ontogenetic stage, light conditions, and life forms (Clark \& Clark, 1992; Poorter et al., 2008; Wright et al., 2010), and hopefully, corrected by phylogenetic bias. The generation of this information has been long overdue, considering that human impacts on natural systems are becoming global and are accelerating the progression of climate change (Loarie et al., 2009), which is likely to affect more intensively shade tolerant species, and in general, species exploiting limited resources and disturbed conditions.

\section{ACKNOWLEDGMENTS}

\section{Rebecca Cole, Javier Cedeño and Willy} González for letting us carry the project at their properties. Zak Zahawi and all the staff of Las Cruces provided logistical support. A special thanks to Laura, Juliana and Julio Cesar González, without their help, this work will have not been possible. This work was supported by The Nature Conservancy (TNC).

\section{RESUMEN}

Crecimiento y supervivencia de plántulas de cinco especies de árboles en bosques secundarios y pastizales adyacentes en un bosque lluvioso montano del sur de Costa Rica. La restauración exitosa del bosque en ambientes tropicales está limitada por la carencia de estudios sobre los requisitos de hábitat, el establecimiento inicial, y la sobrevivencia de las plántulas de la mayoría de las especies de árboles tropicales nativos. En este estudio, evaluamos las respuestas en el crecimiento inicial y el potencial de regeneración de las plántulas de cinco especies de árboles nativos de Costa Rica (Hasseltia floribunda, Inga densiflora, Persea americana, Tapirira mexicana y Trichilia pittieri). Sembramos las plántulas en bosques secundarios y en pastizales abiertos adyacentes con condiciones de luz contrastantes. Cuantificamos el crecimiento, la supervivencia y el daño por herbivoría de las plántulas de forma mensual entre agosto 2010 y agosto 2011, y medimos las diferencias en el la masa foliar por área de la hoja al final del experimento. Existió una variación significativa en el crecimiento de las plántulas expuestas a la sombra en los bosques secundarios y aquellas que crecieron en pastizales. El crecimiento en altura fue mayor en pastizales en todas las especies; I. densiflora, $P$. americana y $T$. mexicana mostraron la mayor diferencia entre ambientes. En contraste, H. floribunda y $T$. pittieri no mostraron diferencias en el crecimiento del diámetro entre ambientes. Con la excepción de T. mexicana, todas las especies mostraron un aumento en herbivoría durante el estudio. En los pastizales, el incremento de la herbivoría fue más rápido en H. floribunda y T. pittieri, mientras que para I. densiflora y $P$. americana fue mayor en el bosque. La sobrevivencia de plántulas fue diferente entre ambientes para todas las especies. La sobrevivencia de H. floribunda e I. densiflora fue mayor en el bosque secundario, mientras que en las demás especies hubo mayor sobrevivencia de plántulas en los pastizales. La masa foliar por área fue mayor en las plántulas que crecieron en los pastizales que en bosque secundario para todas las especies, lo que sugiere que los individuos que crecieron en condiciones de alta incidencia de luz tuvieron mayor tasa fotosintética y mayor capacidad de construcción de la hoja. Debido al rápido crecimiento y alta supervivencia $I$. densiflora y $T$. mexicana tienen gran potencial para la restauración de bosques secundarios y pastizales abandonados. Generar información sobre la respuesta de plántulas creciendo en bosques secundarios y pastizales en regeneración es crítico para mejorar los procesos de restauración de ambientes alterados. La restauración de estos bosques depende de la correspondencia entre las condiciones específicas de hábitat y la plasticidad ecológica de las especies nativas.

Palabras clave: restauración ecológica, pastizales, reforestación, bosque secundario, crecimiento de plántulas, tolerancia a la sombra, ecología de árboles. 


\section{REFERENCES}

Aide, T. M., Clark, M. L., Grau, H. R., López-Carr, D., Levy, M. A., Redo, D., Bonilla-Moheno, M., Riner, G., Andrade-Núñez, M. J., \& Muñiz, M. (2013). Deforestation and reforestation of Latin America and the Caribbean (2001-2010). Biotropica, 45, 262-271.

Alvarado, A., \& Mata, R. (2015). Soils of Costa Rica: An Agroecological Approach. In M. Kappelle (Ed.), Costa Rican Ecosystems (pp. 64-93). Chicago: University of Chicago Press.

Álvarez-Aquino, C., Williams-Linera, G., \& Newton, A C. (2004). Experimental native tree seedling establishment for the restoration of a Mexican cloud forest. Restoration Ecology, 12, 412-418.

Arroyo-Rodríguez, V., \& Mandujano, S. (2006a). The importance of tropical rain forest fragments to the conservation of plant species diversity in Los Tuxtlas, Mexico. Biodiversity and Conservation, 15, 4159-4179.

Arroyo-Rodríguez, V., \& Mandujano, S. (2006b). Forest fragmentation modifies habitat quality for Alouatta palliata. International Journal of Primatology, 27, 1079-1096.

Benitez-Malvido, J., \& Martínez-Ramos, M. (2013). Longterm performance and herbivory of tree seedlings planted into primary and secondary forest of Central Amazonia. Journal of Tropical Ecology, 29, 301-311.

Butterfield, R. P. (1995). Promoting biodiversity: advances in evaluating native species for reforestation. Forest Ecology and Management, 75, 111-121.

Chazdon, R. L. (2003). Tropical forest recovery: legacies of human impact and natural disturbances. Perspectives in Plant Ecology, Evolution and Systematics, 6, 51-71.

Chazdon, R. L., Letcher, S. G., Van Breugel, M., MartínezRamos, M., Bongers, F., \& Finegan, B. (2007). Rates of change in tree communities of secondary Neotropical forests following major disturbances. Philosophical Transactions of the Royal Society B: Biological Sciences, 362, 273-289.

Chazdon, R. L. (2008). Beyond deforestation: restoring forests and ecosystem services on degraded lands. Science, 320, 1458-1460.

Chazdon, R. L., Peres, C. A., Dent, D., Sheil, D., Lugo, A. E., Lamb, D., \& Miller, S. E. (2009). The potential for species conservation in tropical secondary forests. Conservation Biology, 23, 1406-1417.

Chazdon, R. L. (2014). Second Growth: The promise of tropical forest regeneration in an age of deforestation. Chicago: University of Chicago Press.
Clark, D. A., \& Clark, D. B. (1992). Life history diversity of canopy and emergent trees in a neotropical rain forest. Ecological Monographs, 62, 315-344.

Cole, R. J., Holl, K. D., \& Zahawi, R. A. (2010). Seed rain under tree islands planted to restore degraded lands in a tropical agricultural landscape. Ecological Applications, 20, 1255-1269.

Croat, T. B. (1978). Flora of Barro Colorado Island. Stanford, CA, USA: Stanford University Press.

D’Antonio, C., \& Meyerson, L. A. (2002). Exotic plant species as problems and solutions in ecological restoration: a synthesis. Restoration Ecology, 10, 703-713.

Daily, G. C., Ehrlich, P. R., \& Sánchez-Azofeifa, G. A. (2001). Countryside biogeography: use of humandominated habitats by the avifauna of southern Costa Rica. Ecological Applications, 11, 1-13.

Dalling, J. W., Winter, K., Nason, J. D., Hubbell, S. P., Murawski, D. A., \& Hamrick, J. L. (2001). The unusual life history of Alseis blackiana: a shadepersistent pioneer tree? Ecology, 82, 933-945.

Davidson, R., Gagnon, D., Mauffette, Y., \& Hernandez, H. (1998). Early survival, growth and foliar nutrients in native Ecuadorian trees planted on degraded volcanic soil. Forest Ecology and Management, 105, 1-19.

Davidson, R., Mauffette, Y., \& Gagnon, D. (2002). Light requirements of seedlings: a method for selecting tropical trees for plantation forestry. Basic and Applied Ecology, 3, 209-220.

Denslow, J. S. (1987). Tropical rainforest gaps and tree species diversity. Annual Review of Ecology and Systematic, 18, 431-451.

Dent, D. H., \& Wright, S. J. (2009). The future of tropical species in secondary forests: a quantitative review. Biological Conservation, 142, 2833-2843.

Ewel, J. J., O’Dowd, D. J., Bergelson, J., Daehler, C. C., D’Antonio, C. M., Gómez, L. D., Gordon, D. R., Hobbs, R. J., Holt, A., Hopper, K. R., Hughes, C. E., LaHart, M., Leakey, R. R. B., Lee, W. G., Loope, L. L., Lorence, D. H., Louda, S. M, Lugo, A. E., McEvoy, P. B., Richardson, D. M., \& Vitousek, P. M. (1999). Deliberate introductions of species: research needs. BioScience, 49, 619-630.

FAO. (2010). Global Forest Resources Assessment. Roma, Italia: Food and Agriculture Organization of the United Nations.

García-Orth, X., \& Martínez-Ramos, M. (2008). Seed dynamics of early and late successional tree species in tropical abandoned pastures: seed burial as a way of evading predation. Restoration Ecology, $16,435-443$. 
Gardiner, E. S., \& Hodges, J. D. (1998). Growth and biomass distribution of cherry bark oak Quercus pagoda Raf. seedlings as influenced by light availability. Forest Ecology and Management, 108, 127-134.

Gardner, T. A., Barlow, J., Sodhi, N. S., \& Peres, C. A. (2010). A multi-region assessment of tropical forest biodiversity in a human-modified world. Biological Conservation, 143, 2293-2300.

Garnier, E., Shipley, B., Roumet, C., \& Laurent, G. (2001). A standardized protocol for the determination of specific leaf area and leaf dry matter content. Functional Ecology, 15, 688-695.

Gerhardt, K. (1994). Seedling development of four tree species in secondary tropical dry forest in Guanacaste, Costa Rica (Doctoral dissertation). Uppsala University, Uppsala, Sweden.

Gibson, L., Lee, T. M., Koh, L. P., Brook, B. W., Gardner, T. A., Barlow, J., \& Sodhi, N. S. (2011). Primary forests are irreplaceable for sustaining tropical biodiversity. Nature, 478, 378-381.

González, J. \& Poveda, L. J. (2007). Lauraceae. In B. E. Hammel, M. H. Grayum, C. Herrera, \& N. Zamora (Eds.), Manual de Plantas de Costa Rica (Vol. VI, pp. 90-172). Missouri, USA.: Missouri Botanical Garden Press.

González, J. (2010). Flacourtiaceae. In B. E. Hammel, M. H. Grayum, C. Herrera, \& N. Zamora (Eds.), Manual de Plantas de Costa Rica (Vol. V., pp. 782-816). Missouri, USA.: Missouri Botanical Garden Press.

Guariguata, M. R. (2000). Seed and seedling ecology of tree species in neotropical secondary forests: management implications. Ecological Applications, $10,145-154$.

Guariguata, M. R., \& Ostertag, R. (2001). Neotropical secondary forest succession: changes in structural and functional characteristics. Forest Ecology and Management, 148, 185-206.

Harms, K. E., Condit, R., Hubbell, S. P., \& Foster, R. B. (2001). Habitat associations of trees and shrubs in a 50 ha Neotropical forest plot. Journal of Ecology, 89, 947-959.

Häger, A., Otárola, M. F., Stuhlmacher, M. F., Castillo, R. A., \& Arias, A. C. (2015). Effects of management and landscape composition on the diversity and structure of tree species assemblages in coffee agroforests. Agriculture, Ecosystems \& Environment, 199, 43-51.

Harvey, C. A., \& Haber, W. A. (1998). Remnant trees and the conservation of biodiversity in Costa Rican pastures. Agroforestry Systems, 44, 37-68.

Henríquez, C., \& Bertsch-Hernández, F. (1994). Efecto de la aplicación fraccionada del fertilizante potásico en un andisol bajo cultivo de maíz y frijol en Coto Brus, Costa Rica. Agronomía Costarricense, 18, 53-59.

Hoffmann, P. M., Blum, C. T., Velazco, S. J. E., Gill, D. J. C., \& Borgo, M. (2015). Identifying target species and seed sources for the restoration of threatened trees in southern Brazil. Oryx, 49, 425-430.

Holdridge, L. R, Poveda, L. J., \& Jiménez, Q. 1997. Árboles de Costa Rica. San José, Costa Rica: CCT.

Holdridge, L. R. (1978). Ecología basada en zonas de vida. San José, Costa Rica: IICA.

Holl, K. D., Loik, M. E., Lin, E. H., \& Samuels, I. A. (2000). Tropical montane forest restoration in Costa Rica: overcoming barriers to dispersal and establishment. Restoration Ecology, 8, 339-349.

Holl, K. D. (2002). Effect of shrubs on tree seedling establishment in an abandoned tropical pasture. Journal of Ecology, 90, 179-187.

Holl, K. D., Zahawi, R. A., Cole, R. J., Ostertag, R., \& Cordell, S. (2011). Planting seedlings in tree islands versus plantations as a large-scale tropical forest restoration strategy. Restoration Ecology, 19, 470-479.

ITTO, 2002. International Tropical Timber Organisation Guidelines for the Restoration, Management and Rehabilitation of Degraded and Secondary Tropical Forests. Policy Development Series 13.

Jiménez, Q., \& Rodríguez, A. (2006). Meliaceae. In: B. E. Hammel, M. H. Grayum, C. Herrera, \& N. Zamora (Eds.), Manual de Plantas de Costa Rica (Vol. VI, pp. 575-614). Missouri, USA.: Missouri Botanical Garden Press.

Kitajima, K. (1994). Relative importance of photosynthetic traits and allocation patterns as correlates of seedling shade tolerance of 13 tropical trees. Oecologia, 98, 419-428.

Kitajima, K., \& Poorter L. (2008). Functional basis for resource niche partitioning by tropical trees. In W. P. Carson \& S. A. Schnitzer (Eds.), Tropical Forest Community Ecology (pp. 172-188). Oxford: Blackwell.

Koptur, S. (1983). Flowering phenology and floral biology of Inga (Fabaceae: Mimosoideae). Systematic Biology, 8, 354-368.

Leopold, A. C., Andrus, R., Finkeldey, A., \& Knowles, D. (2001). Attempting restoration of wet tropical forests in Costa Rica. Forest Ecology and Management, 142, 243-249.

Letcher, S., \& Chazdon, R. (2009). Rapid recovery of biomass, species richness, and species composition in a forest chronosequence in northeastern Costa Rica. Biotropica, 41, 608-671. 
Lindenmayer, D. B. (2010). Landscape change and the science of biodiversity conservation in tropical forests: a view from the temperate world. Biological Conservation, 143, 2405-2411.

Loarie, S. R., Duffy, P. B., Hamilton, H., Asner, G. P., Field, C. B., \& Ackerly, D. D. (2009). The velocity of climate change. Nature, 462, 1052-1055.

López-Gómez, A. M., Williams-Linera, G., \& Manson, R. H. (2008). Tree species diversity and vegetation structure in shade coffee farms in Veracruz, Mexico. Agriculture, Ecosystems and Environment, 124, 160-172.

Lusk, C. H., Reich, P. B., Montgomery, R. A., Ackerly, D. D., \& Cavender-Bares, J. (2008). Why are evergreen leaves so contrary about shade? Trends in Ecology \& Evolution, 23, 299-303.

Markesteijn, L., \& Poorter, L. (2009). Seedling root morphology and biomass allocation of 62 tropical tree species in relation to drought- and shade-tolerance. Journal of Ecology, 97: 311-325.

Martínez-Garza, C., Tobon, W., Campo, J., \& Howe, H. F. (2013). Drought mortality of tree seedlings in an eroded tropical pasture. Land Degradation \& Development, 24, 287-295.

Martínez-Ramos, M., \& Soto-Castro, A. (1993). Seed rain and advanced regeneration in a tropical rain forest. Vegetatio, 107, 299-318.

Melo, F. P., Arroyo-Rodríguez, V., Fahrig, L., Martínez-Ramos, M., \& Tabarelli, M. (2013). On the hope for biodiversity-friendly tropical landscapes. Trends in Ecology \& Evolution, 28, 462-468.

Mexal, J. G., Rangel, R. C., Negreros-Castillo, P., \& Lezama, C. P. (2002). Nursery production practices affect survival and growth of tropical hardwoods in Quintana Roo, Mexico. Forest Ecology and Management, $168,125-133$.

Muñiz-Castro, M. A., Williams-Linera, G., \& Benítez-Malvido, J. (2015). Restoring montane cloud forest: establishment of three Fagaceae species in the old fields of central Veracruz, México. Restoration Ecology, 23, 26-33.

Nepstad, D. C., Uhl, C., Pereira, C. A., \& da Silva, J. M. C. (1996). A comparative study of tree establishment in abandoned pasture and mature forest of eastern Amazonia. Oikos, 76, 25-39.

Osnas, J. L., Lichstein, J. W., Reich, P. B., \& Pacala, S. W. (2013). Global leaf trait relationships: mass, area, and the leaf economics spectrum. Science, 340, 741-744.

Palma, A. C. \& Laurance, S. G. W. (2015). A review of the use of direct seeding and seedlings plantings in restoration: what do we know and where should we go? Applied Vegetation Science, 18, 561-568.

Palow, D. T., \& Oberbauer, S. F. (2009). Soil type affects seedling shade response at low light for two Inga species from Costa Rica. Plant and Soil, 319, 25-35.

Pinheiro, J., Bates, D., DebRoy, S., Sarkar, D., \& R Core Team (2014). nlme: Linear and Nonlinear Mixed Effects Models. $R$ package version 3.1-118, http:// CRAN.R-project.org/package $=$ nlme.

Poorter, H., \& De Jong, R. (1999). A comparison of specific leaf area, chemical composition and leaf construction costs of field plants from 15 habitats differing improductivity. New Phytologist, 143, 163-176.

Poorter, L., Wright, S. J., Paz, H., Ackerly, D. D., Condit, R., Ibarra-Manríquez, G., \& Wright, I. J. (2008). Are functional traits good predictors of demographic rates? Evidence from five neotropical forests. Ecology, 89, 1908-1920.

Poorter, H., Niinemets, Ü., Poorter, L., Wright, I. J., \& Villar, R. (2009). Causes and consequences of variation in leaf mass per area (LMA): a meta-analysis. New Phytologist, 182, 565-588.

Quinn, G. P., \& Keough, M. J. (2002). Experimental design and data analysis for biologists. UK: Cambridge University Press.

Reich, P. B., Walters, M. B., \& Ellsworth, D. S. (1997). From tropics to tundra: global convergence in plant functioning. Proceedings of the National Academy of Sciences, 94, 13730-13734.

Reich, P. B., Tjoelker, M. G., Walters, M. B., Vanderklein, D. W., \& Buschena, C. (1998). Close association of RGR, leaf and root morphology, seed mass and shade tolerance in seedlings of nine boreal tree species grown in high and low light. Functional Ecology, 12, 327-338.

Reich, P. B. (2014). The world-wide 'fast-slow' plant economics spectrum: a traits manifesto. Journal of Ecology, 102, 275-301.

Rich, P. M. (1990). Characterizing plant canopies with hemispherical photographs. Remote Sensing Reviews, 5, 13-29.

Rickert, E. (2005). Environmental effects of the coffee crisis: A case study of land use and avian communities in Agua Buena, Costa Rica (M.Sc. Dissertation). Evergreen State College, Olympia, Washington.

Sarkar, D. (2008) Lattice: Multivariate Data Visualization with $R$. New York: Springer. ISBN 978-0-387-75968-5

Sugiyama, A., \& Peterson, C. J. (2013). Edge effects act differentially on multiple early regeneration stages of 
a shade-tolerant tree Tapirira mexicana. Biotropica, $45,37-44$.

Therneau, T. (2014). A Package for Survival Analysis in $S$. R package version 2.37-7, http://CRAN.R-project. org/package= $=$ survival.

Valladares, F., \& Niinemets, Ü. (2008). Shade tolerance, a key plant feature of complex nature and consequences. Annual Review of Ecology, Evolution, and Systematics, 39, 237-257.

Villar, R., Ruiz-Robleto, J., Quero, J. L., Poorter, H., Valladares, F., \& Marañón, T. (2004). Tasas de crecimiento en especies leñosas: aspectos funcionales e implicaciones ecológicas. In F. Valladares (Ed.), Ecología del bosque mediterráneo en un mundo cambiante (pp. 191-227). Madrid, España: EGRAF.

Weber, M., Günter, S., Aguirre, N., Stimm, B., \& Mosandl, R. (2008). Reforestation of abandoned pastures: silvicultural means to accelerate forest recovery and biodiversity. In E. Beck, J. Bendix, I. Kottke, F. Makeschin, \& R. Mosandl (Eds.), Gradients in a tropical mountain ecosystem of Ecuador (pp. 431-441). Berlin, Germany: Springer.

Wehncke, E. V., \& Dalling, J. W. (2005). Post-dispersal seed removal and germination selected tree species dispersed by Cebus capucinus on Barro Colorado Island, Panama. Biotropica, 37, 73-80.
Wheelwright, N. T., Haber. W. A., Murray, K. G., \& Guindon, C. (1984). Tropical fruit-eating birds and their food plants: A survey of a Costa Rican lower montane forest. Biotropica, 16, 173-192.

Wolstenholme, B. N., \& Whiley, A. W. (1999). Ecophysiology of the avocado (Persea americana Mill.) tree as a basis for pre-harvest management. Revista Chapingo Serie Horticultura, 5, 77-88.

Wright, S. J., \& Muller-Landau, H. C. (2006). The Future of Tropical Forest Species. Biotropica, 38, 287-301.

Wright, S. J. (2010). The future of tropical forests. Annals of the New York Academy of Sciences, 1195, 1-27.

Wright, S. J., Kitajima, K., Kraft, N. J., Reich, P. B., Wright, I. J., Bunker, D. E., \& Zanne, A. E. (2010). Functional traits and the growth-mortality trade-off in tropical trees. Ecology, 91, 3664-3674.

Zahawi, R. A., Duran, G., \& Kormann, U. (2015). SixtySeven Years of Land-Use Change in Southern Costa Rica. PloS one, 10, e0143554.

Zamora, N., \& Pennington, T. (2001). Guabas y cuajiniquiles de Costa Rica (Inga spp.). Heredia, Costa Rica: INBio. 
